\title{
Value Relevance of Gender Equality in Buginese and Makassarese Culture
}

\author{
Fatmawati Wardihan ${ }^{1}$, Rabina Yunus ${ }^{2}$, Adnan Nasution ${ }^{3}$ \\ \{fatmawatiwardihan@yahoo.com ${ }^{1}$,rabinayunus@yahoo.com ${ }^{2}$,adnan_ugm@yahoo.com ${ }^{3}$ \} \\ Hasanuddin University, Makassar, Indonesia ${ }^{1,2,3}$
}

\begin{abstract}
The study aims to assess and to analyze the value relevance of gender equality in Makassarese and Buginese Culture. As for the locus, the locus of the study is Bone Regency and Gowa Regency in South Sulawesi through the social-cultural approach. The data collection method applies field methods such as interviews and literature review sources. The analysis used in this research is various issues of gender, specifically in the family, personal and organizational contexts. The result of this study indicates that there is value relevance of gender equality in the Buginese and Makassarese culture. The value of gender equality in the Buginese and Makassarese culture study is sipakatau value teaching to treat others well and look at people with all their advantages. Therefore the culture sipakatau upholds the value of mutual respect among others, does not recognize arbitrary actions against others, and even individual problems become a common problem.
\end{abstract}

Keywords: Relevance, Gender Equality, Cultural Values Buginese, and Makassarese.

\section{Introduction}

Many countries experience a large increase in the labor market participation of women. This development often referred to as the gender revolution [1], [2]. The issues of gender equality have been increasingly discussed among Indonesian academics. This study of emerging woman's issues is dominant because of the people's concern of the reality reflecting a woman's position in various aspects of life. Gender roles and gender ideology at the community level play an active role in managing the family, including the division of household works [3], [4]. However, the woman's position is generally attributed and limited to the domestic context in relation to the family matters and household matters, while the man's position is always attributed to the public context in relation to the public matters. The women that propose to participate in the public still have difficulties in freeing themselves from their domestic responsibilities. This additional burden is due to their childcare responsibility that is already very common in their cultural perception [5].

Gender equality is a paradigm that is necessary to impose through diffusion and innovation of gender equality values. The insights and the ideology of Equal partnership should be understood by any citizen. The culture adopted by the community is familialism ideology, where the man's primary role is the head of the household. The man has privileges and the greatest authority in family life [6].

The Buginese and Makassarese community are some of the ethnical groups lived in Indonesia that has their own perspectives about human's existence. The human existence in 
Buginese culture certainly has different characteristics from other cultures. The terms 'Buginese' and 'Makassarese' become the identity for the major community settling in the South Sulawesi peninsula. They have built their civilization for centuries. The wisdom and the teaching within the Buginese and the Makassarese culture are one of the riches humanitarian wealth that exists in the world, especially in Indonesia and it has been passed down through the generations, whether by oral tradition or written tradition that long have been known by the Buginese and Makassarese people in the form of folklore. From those traditions, the Buginese and Makassarese people develop their culture. There are many known cultural records and folklores which give an explanation about human beings, including an explanation about women in the Buginese and Makassarese culture.

The transition of Buginese and Makassarese community from the traditional era to the modern era pass through a long and complex process. There are many cultural values still preserved, but there are some other values gradually abandoned due to interaction with other dominating cultural values. One of the values experiences the cultural shift is in accordance with the changes within the social condition of the community. This development is mostly related to the demands of equal rights for women roles, which is led by the feminist group. Therefore the authors wanted to examine the value relevance of gender equality in the Buginese-Makassarese culture.

\section{Research Methodology}

This study uses a social-cultural approach with social construction consideration that will be the analysis tool for various gender issues, especially in the family, personal, and organizational context. The concept of gender is strongly influenced by the values, both social values, and culture. As for the locus, the locus of this study is Bone Regency and Gowa Regency in South Sulawesi. This study uses a triangulation technique where the researcher uses multiple qualitative data collection techniques, such as nonparticipant observation, interviews, questionnaires, and documentation for similar sources simultaneously. The advantage of the triangulation technique is that the collected data will be more consistent, empirical, and complete. The data analysis applies descriptive statistics analysis using frequency distribution table

\section{Result and Discussion}

\subsection{Description of GDI and GEI in South Sulawesi}

The success rate of development that accommodated the gender issues currently can be measured, one of which is with GDI (Gender Development Index). GDI aims to evaluate and compare the performance of countries on gender equality and aims to measure the position of women compared with men GDI elaborates on the development of men and women. Therefore, this index is able to reveal the gap between the two genders. GDI encompasses some aspects including life expectancy, education, and income, but it uses the index that is distributed equally, separating men and women. In Indonesia, specifically, in Sulawesi, Gender Development Index has shown some great participation of women towards gender equality. The following table below shows the Gender Development Index in Sulawesi. 
Table 1. The Construction of Gender in Sulawesi Island

\begin{tabular}{lccccc}
\hline \multirow{2}{*}{ Province } & \multicolumn{4}{c}{ Gender Development Index (GDI) } \\
\hline North Sulawesi & 9013 & 2014 & 2015 & 2016 & 2017 \\
Central Sulawesi & 93.75 & 94.58 & 94.64 & 95.04 & 94.74 \\
South Sulawesi & 92.34 & 93.69 & 92.25 & 91.91 & 92.66 \\
Southeast Sulawesi & 89.24 & 89.56 & 92.92 & 92.79 & 92.84 \\
West Sulawesi & 88.56 & 89.18 & 90.30 & 90.23 & 90.24 \\
Gorontalo & 84.57 & 85.09 & 85.82 & 89.35 & 89.44 \\
\hline
\end{tabular}

Source : BPS, 2017

According to the BPS 2017, GDI in Sulawesi, especially South Sulawesi Province, shows an increase every year. South Sulawesi has the second-highest value of GDI after North Sulawesi.

Table 2. Gender Empowerment Index in Sulawesi Island

\begin{tabular}{lccccc}
\hline \multirow{2}{*}{\multicolumn{1}{c}{ Province }} & \multicolumn{5}{c}{ Gender Empowerment Index (GEI) } \\
\cline { 2 - 6 } & 2013 & 2014 & 2015 & 2016 & 2017 \\
\hline North Sulawesi & 75.55 & 76.15 & 79.82 & 81.24 & 82.37 \\
Central Sulawesi & 68.59 & 65.11 & 65.57 & 70.05 & 70.38 \\
South Sulawesi & 64.42 & 66.76 & 67.98 & 70.02 & 70.57 \\
Southeast Sulawesi & 64.49 & 68.13 & 72.14 & 70.51 & 70.76 \\
West Sulawesi & 64.47 & 67.14 & 69.40 & 71.71 & 73.37 \\
Gorontalo & 60.89 & 67.36 & 69.26 & 69.70 & 71.09 \\
\hline
\end{tabular}

Source: BPS, 2017

The data from BPS shows that there is a significant increase in Gender Development Index (GEI) in South Sulawesi that accounts for 70.57. The value keeps increasing every year, and GEI of South Sulawesi also has the second-highest value after North Sulawesi. Woman empowerment program aims to provide women with the opportunity and access to the balance of the development process [7].

\subsection{Description of South Sulawesi in the Social Economy Aspect}

A general overview of gender in South Sulawesi in the social economy shows that there is still a small gap between men and women. Where such gaps are visible in terms of education. The ratio of literacy rates based on the province, area of residence, and gender in 2017 accounted for $97.70 \%$ for men and $96.41 \%$ for women. Similarly, in the health aspect, the ratio of life expectancy of a woman is higher than a man in 2017. For men, the ratio accounted for $67.96 \%$, while the women accounted for $71.86 \%$. While in the economic aspect, the amount of expenditure per capita of men is higher than women. In 2017, man expenditure is Rp.15,010, while woman expenditure is Rp.9,379 (Source: Central Bureau Of Statistics). In terms of political involvement, the women in the parliament reached $21.18 \%$ in 2017 , while the percentage of women as professionals reached $51.62 \%$ in 2017 . This percentage had decreased compared to previous years. 


\subsection{Value of Gender Equality in the Buginese and Makassarese Culture}

Gender equality is defined as the equality of man and woman for having opportunities and rights as a human that they could participate in various aspects of life. In a further development, women sometimes are considered to be domestic being due to life demand that is gradually justified by the community as the second sex. This further generates the feminist movement with a variety of shapes and demands for liberating women from isolated domestication [8]. For women, power can encourage empowerment by increasing their participation in taking a decision on the allocation of household resources, mobility, and labor participation [9], [10], [11].

Arnold (2006) states that there are three models or developmental approaches in achieving gender equality. Those are the women in development (WID) approach, women and development (WAD) approach, and gender and development (GAD) approach. The WID approach requires women participation $\mathrm{n}$ the development, but the focus is not on the change of the overall structure of a community or its economic system that causes a gap between men and women. WAD approach integrates the women in the development only to worsen their opportunities in achieving equality. However, this approach is also criticized because of the assumption that women's status will be improved if the global structure becomes more equitable, and GAD also considers empowerment a complex process and influences by the political, social, and economic conditions. This approach focuses on empowering women having no good opportunities in developing their prosperity within the community [12].

According to Puspitawati (2012), the value of gender equality is described as a gender partnership that manifests in various forms [13], those are: first, equal and fair cooperation between husband and wife as well as children, either men or women, in performing all the functions of the family through the division of work and roles including public, domestic and social roles[14],[8]. Second, partnerships in the role division of husband and wife to work on family life activity and to show transparency of the resource use. "There should be no lie between the husband and the wife" or "there is no secret agenda or have an axe to grind", the emergence of a sense of interdependence is based on the trust and respect each other, accountability in the resource management, and the establishment of stable, harmony and well organized family life that reflects the existence of 'good governance' in the family level [15]. Third, partnerships in husband and wife role division are related to the cooperation in carrying out the family function with behavioral components including the contribution of ideas, attention, moral support and material, the advice based on the knowledge gained, and the support in terms of energy and time [3]. Fourth, gender partnership in this context refers to a concept of gender in relation to the different roles, functions, responsibilities, needs, and social status between men and women based on the formation/ construction of public culture; social role of gender is not natural, but it is based on the agreement of the community; Social roles can be interchanged and can change depending on local cultural conditions and time/era [16]. The role of a husband-wife or father-mother is the consequence of marital life. The division of tasks and roles of husband and wife is usually performed based on a compromise with the partner.

Values or the principle of gender equality mentioned above have familiarity in Makassarese and Buginese culture. Values of equality in the Buginese and Makassarese culture is reflected from the understanding of the concept of "Tau" or "To" in the Buginese and Makassarese terminology that means human, in the cultural perspective of South Sulawesi, it is also recommended to have sipa' tau (human nature). It means that the characteristics of human nature should refer to the system of values and norms of the South Sulawesi community. The implementation of the concept further developed into ethics of 
sipakatau (to humanize each other), sipakalebbi (to respect each other), sipakatuo (to support each other), and sipakatokkong (to help each other). Therefore, it is very clear that the philosophy is not only as a cultural will, but also as a value system and guidance of life for the community in South Sulawesi. This implies that the cooperation principle between man and woman or among the women themselves and among the men themselves is no matter how difficult the works, it will, in turn, be successful. This value is known as mutual cooperation (gotong royong).

In the Buginese and Makassarese culture, the philosophy burane mallempa makkunrai majjujunjung, that means the man shall carry (2 parts) and the woman shall uphold (1 part). This is the mechanism of the job division in the tasks of the household, where the husband obligated to support a wife and take care of the household. However, this work division is not an obligation, which implies that it is not prohibited for the husband to work the wife's work if the wife is unable to do the works. Similar to the wife, the wife is not strictly obliged to only take care of the household works. Even sometimes, the husband and the wife work together. This is what Buginese and Makassarese people called sipurepo or to share the works with each other.

In addition to that, Buginese society has cultural value known as sibaliperri' (solidarity, partnership). While in the context of the 'iddah, it is related to the culture of siri' (honor and self-esteem) and asitinajang (the principle of propriety), lempu' (honesty), and other. In addition, in the problem of division of inheritance is closely related to the philosophy of mallempa' (to bear) and majjujung (to uphold), which means the man with his right of inheritance, on the other hand, has an obligation to support his sisters, while the daughter also has the right of inheritance, but she is responsible for herself. In the application of inheritance, the Buginese people also refer to the assitinajang (the principle of propriety) in either cultural or religious scope, which is to obey the religion and culture.

Meanwhile, at the wedding ceremony of the Buginese and the Makassarese culture, it is very important to concern with the value of gender equality between the man and women. This is reflected from the semantical meaning of the word marriage, Siala among the Buginese and Sialle' among the Makassarese that means 'to take each other'. Wedding. The marriage between the man and the woman is understood as a process of taking each other. The implementation of Siala or taking each other in general is when the woman takes the man. In this case, the man who recently gets married is obliged to stay in the house of the bride's parents. In South Sulawesi, the Buginese and Makassarese wedding procession is more inclined and dominated by the bride. Almost all decisions are made and confirmed in the bride's house.

\subsection{The Division of Gender Work According to The Buginese and Makassarese Culture}

Gender relations is emphasized on the cultural construction that encompasses domestic roles, productive roles, and social roles. The role of the production sector of Buginese and Makassarese community in Bone and Gowa Regency is presented in table 3 and table 4.

Table 3. The Role of Production Sector of Bone Community

\begin{tabular}{lcccc}
\hline \multicolumn{1}{c}{ Item } & Weight & Frequency & Score & $\%$ \\
\hline Both & 3 & 22 & 66 & 81.5 \\
Women & 2 & 7 & 14 & 17.3 \\
\hline
\end{tabular}




\begin{tabular}{lcccc}
\hline Men & 1 & 1 & 1 & 1.2 \\
Total & & 30 & 81 & 100 \\
Mean & & & 0.37037 & \\
\hline
\end{tabular}

Source: processed primary data, 2018.

Table 4. The Role of The Production sector in Gowa

\begin{tabular}{lcccc}
\hline \multicolumn{1}{r}{ Item } & Weight & Frequency & Score & $\%$ \\
\hline Both & 3 & 26 & 78 & 91.8 \\
Women & 2 & 3 & 6 & 7.0 \\
Men & 1 & 1 & 1 & 1.2 \\
Total & & 30 & 85 & 100 \\
Mean & & & 0.352941 & \\
\hline
\end{tabular}

Source: processed primary data, 2018.

Based on table 3 and 4, they show that the role undertaken by both women and men is the highest percentage in two districts that accounts for $81.5 \%$ and $91.8 \%$ respectively. It shows that the productive roles for the Buginese and Makassarese people in Bone and Gowa Regency adopt gender equality concept. Man and woman respect their rights and obligation each other. This is supported by the Nyamn [17], that gender is the important aspect of how husband and wife keep each other, to keep their relationship, and their daily life. Both of them describe, define and understand the action, personality and their own personal character to achieve harmony for them [15].

The role of reproductive sector of Buginese and Makassarese in bone and Gowa Regency is presented in table 5 and 6.

Table 5. The Role Of The Sector Of The Reproduction Of The Bone

\begin{tabular}{lcccc}
\hline \multicolumn{1}{c}{ Item } & Weight & Frequency & Score & $\%$ \\
\hline Both & 3 & 30 & 90 & 100 \\
women & 2 & 0 & 0 & 0 \\
men & 1 & 0 & 0 & 0 \\
Total & 30 & 90 & 100 \\
Mean & \multicolumn{5}{c}{0.333333} \\
\hline \multicolumn{5}{c}{ Source: processed primary data, 2018. }
\end{tabular}

Table 6. The role of the Reproductive sector in Gowa Regency

\begin{tabular}{lcccc}
\hline \multicolumn{1}{c}{ Item } & Weight & Frequency & Score & $\%$ \\
\hline Both & 3 & 30 & 90 & 100 \\
Woman & 2 & 0 & 0 & 0 \\
Man & 1 & 0 & 0 & 0 \\
\hline
\end{tabular}




\begin{tabular}{lccc}
\hline Total & 30 & 90 & 100 \\
Mean & & 0.333333 & \\
\hline
\end{tabular}

Source: processed primary data, 2018.

Tables 5 and 6 show that the reproductive sector activity of the Buginese and Makassarese community in Bone and Gowa regency accounts for $100 \%$, and it is done collectively.

The role of the social sector of Buginese and Makassarese community in Bone and Gowa is presented in table 7 and table 8 .

Table 7. The Role Of Social Sector in Bone Regency

\begin{tabular}{lcccc}
\hline Item & Weights & Frequency & Score & $\%$ \\
\hline Both & 3 & 30 & 90 & 100 \\
Woman & 2 & 0 & 0 & 0 \\
Man & 1 & 0 & 0 & 0 \\
Total & & 30 & 90 & 100 \\
Mean & & & 0.333333 & \\
\hline
\end{tabular}

Source: processed primary data, 2018.

Table 8. The Role Of Social Sector in Gowa Regency

\begin{tabular}{lcccc}
\hline Item & Weights & Frequency & score & Percentage \\
\hline Both & 3 & 30 & 90 & 100 \\
Woman & 2 & 0 & 0 & 0 \\
Man & 1 & 0 & 0 & 0 \\
Total & & 30 & 90 & 100 \\
Mean & & & 0.333333 & \\
\hline
\end{tabular}

Source: processed primary data, 2018.

Tables 7 and 8 show that the social activity of the Buginese and Makassarese community in Bone and Gowa regency is done collectively involving women and men reaching the highest percentage that accounts for $100 \%$. Generally, the role of men and women in the household works, including agricultural production, are associated with the time spent on working various activities. Women wake up first in the morning, prepare food for all family members, and take care of the children before they go to school. After their morning works are finished, they go to work in the fields, then return home to prepare lunch, and some of them will return to the fields to work until the afternoon.

During the harvest season, although they work near the house, they have a variety of responsibilities, which is quite time-consuming in some post-harvest processes. The men work in the field in the morning, and they finish working in the evening, but they can have a rest in the afternoon. In the afternoon, women can do a variety of other activities, including marketing and unproductive activities during their leisure time. 


\subsection{The Level of Gender Equality of The Buginese and The Makassarese Community}

Conceptually, all human beings desire equality and equity, but naturally, gender is a separation between man and woman. Gender differences have an impact on a variety of injustice, both for men and especially for women. Gender inequality is manifested in the various forms of injustice, namely: the marginalization of the process of impoverishment of the economy, subordinated to the rights of women, stereotyping on women through negative labeling, and woman's burden for a longer working hour [14]. Gender equality is a dynamic condition that leads men and women to obtain access, participation, control, and benefits equally. To understand the level of equality and gender equity in South Sulawesi, the author provides a categorization, as can be seen in table 9 below.

Table 9. Category of Gender Equality and Equity Level

\begin{tabular}{lcc}
\hline \multicolumn{1}{c}{ Category } & Range of Score & $\%$ \\
\hline High & $241-360$ & $66.67-100$ \\
Moderate & $121-240$ & $33.34-66.66$ \\
Low & $0-120$ & $0-33.33$ \\
\hline \multicolumn{3}{c}{ Source: processed primary data, 2018. }
\end{tabular}

Based On table 9. The level of Gender Equality of the Buginese and Makassarese community is still relatively moderate. The explanation can be seen in table 10 and 11 .

Table 10. The Level of Gender Equality in Bone Regency

\begin{tabular}{lcccc}
\hline & Access & Participation & Control & Benefits \\
\hline Total & 54 & 33 & 40 & 63 \\
Mean & 1.8 & 1.1 & 1.3 & 2.1 \\
Validation & 0.818209 & 0.7397164 & 0.717886 & 0.733702 \\
Total & \multicolumn{3}{c}{190} \\
\hline
\end{tabular}

Source: processed primary data, 2018.

Table 11. The level of Gender Equality in the District of Gowa

\begin{tabular}{lcccc}
\hline & Access & Participation & Control & Benefits \\
\hline Total & 57 & 50 & 57 & 63 \\
Mean & 1.9 & 1.6666667 & 1.9 & 2.1 \\
Validation & 0.947109 & 0.7284665 & 0.961099 & 0.620051 \\
Total & & \multicolumn{3}{c}{227} \\
Source: processed primary data 2018 & \multicolumn{3}{l}{}
\end{tabular}

According to Tables 10 and 11, the level of gender equality and equity of the Buginese and Makassarese community in Bone and Gowa Regency accounts for 190 and 227, respectively. In accordance with the categories above, the level of gender equality and equity 
is still classified as moderate. This proves that the cultural values of the Buginese and Makassarese community have relevance to the principles of gender equality and equity.

\section{Conclusions}

Based on the description above, it can be concluded that the values of gender equality generally has relevance to Buginese and Makassarese culture that the philosophical values of Buginese and Makassarese culture include burane mallempa, makkunrai majjujung, which means man's primary task is 'to bear' (2 parts) and woman's task is 'to uphold' (1 part). In the mechanism of household work division, the husband obligated to support wife and the take care of the household. However, this work division is not an obligation which implies that it is not prohibited for the husband to work the wife's work if the wife is unable to do the works. Similar to the wife, the wife is not strictly obliged to only take care of the house hold works. Even sometimes, the husband and the wife work together. This is what Buginese and Makassarese people called sipurepo or to share the works with each other. Not only that, in the Buginese and Makassarese culture, but the value of sipakatau also teaches people to always treat other people well and to respect for their good virtues. Therefore, culture sipakatau uphold the value of mutual respect among the people, to behave properly, and to solidarity. While in the concept of siri' masiri', it teaches people how to be encouraged and be successful in their works in any time, so that it can be beneficial to themselves and to the people around them. In addition to that, this concept also encourages people's enthusiasm in any situation.

Based on the study result, the level of gender equality and equity of the Buginese and Makassarese community is classified as moderate since the principles in Buginese and Makassarese culture have similarities to gender equality principles. Therefore, the implication or the application of gender mainstreaming in developing gender equality can be implemented in the Buginese and Makassarese culture.

Acknowledgment. The authors would like to express their gratitude to the Ministry of Research, Technology, and Higher Education of Indonesia. The authors would like to express their gratitude thanks to local people in Bone and Gowa Regency to conduct the research.

\section{Reference}

[1] Hochschild, A.: "Muchung, Anne. The Second Shift.” New York: Avon Books (1989)

[2] Lundqvist, A.: Family policy paradoxes: gender equality and labour market regulation in Sweden, 1930-2010. Policy Press (2011)

[3] Geist, C.: "The welfare state and the home: Regime differences in the domestic division of labour," Eur. Sociol. Rev., vol. 21, no. 1, pp. 23-41 (2005)

[4] Greenstein, T. N.: "National context, family satisfaction, and fairness in the division of household labor," J. Marriage Fam., vol. 71, no. 4, pp. 1039-1051 (2009)

[5] Abdullah, A.: "Kesetaraan Gender di Perguruan Tinggi Islam," Yogyakarta McGill-IAINIndonesia Soc. Equity Proj. (2004)

[6] Kusujiarti, S.: "Antara ideologi dan transkrip tersembunyi: Dinamika hubungan gender dalam masyarakat Jawa," Abdullah, Irwan. Sangkan Paran Gender. Yogyakarta: Pustaka Pelajar, (1997)

[7] Elizabeth, R.: "Pemberdayaan wanita mendukung strategi gender mainstreaming dalam kebijakan pembangunan pertanian di perdesaan," in Forum penelitian agro ekonomi, vol. 25, no. 2, pp. 126-135 (2016) 
[8] Iswary, E., and Hum, M., Perempuan Makassar; Relasi Gender dalam Folklor. -, (2010)

[9] Iversen, T., and Rosenbluth, F.: "The political economy of gender: Explaining cross-national variation in the gender division of labor and the gender voting gap," Am. J. Pol. Sci., vol. 50, no. 1, pp. 1-19 (2006)

[10] Ashraf, N., Karlan, D., and Yin, W.: "Female empowerment: Impact of a commitment savings product in the Philippines," World Dev., vol. 38, no. 3, pp. 333-344 (2010)

[11] Aslam, M., and Kingdon, G. G.: "Parental education and child health-understanding the pathways of impact in Pakistan," World Dev., vol. 40, no. 10, pp. 2014-2032 (2012)

[12] Fakih, M.: Menggeser konsepsi gender dan transformasi sosial. Pustaka Pelajar (1995)

[13] Umar, N.: "Argumen Kesetaraan Gender Perspektif Alquran Jakarta, hlm. 23." Paramadina, (2001)

[14] Sumiyatiningsih, D.: "Pergeseran Peran Laki-Laki dan Perempuan dalam Kajian Feminis," dalam WASKITA, J. Stud. Agama dan Masy. (2014)

[15] Puspitawati, H. "Gender dan keluarga: konsep dan realita di Indonesia," (2010)

[16] Puspitawati, H.,: "Kemitraan peran gender dalam keluarga," pp. 1-22.

[17] Nyman, C., Reinikainen, L., and Eriksson, K.: "The tension between gender equality and doing gender: Swedish couples' talk about the division of housework," in Women's Studies International Forum, vol. 68, pp. 36-46 (2018) 